\title{
Determinant Analysis of Recovery Treatment for Tuberculosis Patients in Medan City
}

\author{
Chinta Yolanda Sari ${ }^{1}$ \\ Student of Magister Departement of Epidemiology \\ University of Sumatera Utara (USU) \\ Medan, Indonesia \\ cintayolanda90@yahoo.com
}

\author{
Sorimuda Sarumpaet ${ }^{2,}$ Fazidah Aguslina Siregar ${ }^{3}$ \\ Lecturer of Departement of Epidemiology \\ University of Sumatera Utara (USU) \\ Medan, Indonesia \\ sorimudasarumpaet@yahoo.com, fazida65@yahoo.com
}

\begin{abstract}
Tuberculosis is still global problem in the world. Indonesia was the second ranked with the highest Tuberculosis cases in the world. Based on the National Tuberculosis Program, the success rate of Tuberculosis treatment is $85 \%$. Medan city is one area in North Sumatera Province with high incidence of Tuberculosis, however the cure rate is still below the national target of $74,02 \%$. The purpose of this study was to determinant the factors that influence recovery treatment for Tuberculosis patient in Medan City. The study design this is case control study. Cases were Tuberculosis patient cases who were not cured and controls were the recovered tuberculosis patient. The sample consisted of 70 cases and 70 control. Data analysis is using multiple logistic regression. The result showed that knowledge, nutritional status, and medication compliance were predictors for recovery treatment of Tuberculosis patients with the model equation recovery treatment for Tuberculosis patients $=-4,617+$ 1.515 (knowledge) + 1,692 (nutritional status) + 2,700 (medication compliance). The Population Attributable Risk (PAR) showed $\mathbf{8 1 , 5 8 \%}$, risk of recovery treatment for Tuberculosis patients could be avoided if people have a normal nutritional status. It was recommended that health promotion on the importance of regular treatment and monitoring nutritional status should be enhanced.
\end{abstract}

\section{Keywords-Recovery Treatment; Determinant; Tuberculosis Patient}

\section{INTRODUCTION}

Tuberculosis (TB) is still a global health problem in the world and one-third of the world population is infected. TB is the leading cause of death in the world and infection agents. In 2002-2020 approximately one billion people will be infected with TB. The Increased incidence of TB cases is higher in Asia and Africa than in Europe and America. In 2016 there were 10,4 million cases of TB where one point three million death were Human Immunodeficiency Virus (HIV) negative and 374.000 TB (HIV positive). 90\% of TB cases occur in adult, $65 \%$ in men and $10 \%$ of people with HIV. $95 \%$ of cases of pulmonary $\mathrm{TB}$ occur in relatively poor developing countries [1].

TB is an infectious disease caused by Mycobacterium Tuberculosis that is transmitted through the air. This bacterium is a very strong bacillus bacteria that it takes a long time to treat it, in addition to the boredom of having to take medication in a long time a patient sometimes stop taking medication before the mass of this treatment with various factors. Non compliance with treatment means TB patients remain infectious longer, more likely to relapse resulting in treatment failure as wel as drug resistant TB [2].

Based on the Annual Report on Global TB control 2017, Indonesia is one of 22 countries with high burden countries. In 2012 fourth ranked with the highest pulmonary tuberculosis cases in the world of 0.37-0.54 million after India (2.0-2.5 million, China (0.9-1.2 million) and South Africa (0.40-0.59 million). In 2017, Indonesia is $2^{\text {nd }}$ ranked with the number of TB cases 1.020 million after India 2.790 million [3].

The based on Tuberculosis Program sets a $90 \%$ success rate of treatment success and an $85 \%$ cure rate but a world TB recovery rate of $66 \%$. Recorded incident $\mathrm{TB}$ resistant is 0.5 million per year. Increased incidence of TB resistant results in the cure of tuberculosis inhibited, requiring a long time and medical expenses. The effort of TB control program with strategy Directly Observed Treatment Shortcourse (DOTS) has been started since 1955, established World Health Organization (WHO) is direct supervision to swallow short term drug everyday by Supervisor of Drugs Swallowing (PMO). The purpose of DOTS is to achieve maximum cure rate. The global success rate of treatment in Indonesia has reached the national target but there are still some provinces in Indonesia where the rate of treatment failure is less than $90 \%$ are west Papua (56.9\%), Papua (64.4\%), Maluku (64.5\%) North Maluku (72.0\%), Bali (76.6\%), Gorontalo (76.7\%), Central Java (76.9\%) Riau Islands $(79.2 \%)$, Jakarta $(79.7 \%)$, Central Kalimantan (82.1\%), Special Region Yogyakarta $(82.3 \%)$, Southeast Sulawesi $(83.2 \%)$, West Sumatera (83.6\%) and Bangka Belitung Islands (84.0\%) One of the efforts to control tuberculosis by treatment Indicators used to evaluated tuberculosis through Succe ss rate. Success rate is total all cure cases and complete treatment reported and reported TB cases [4].

In Indonesia TB is the number one cause of death of the largest class of infectious diseases and number three causes of death at all ages after cardiovascular disease and acute channel infection disease. In 2015 the estimated incidence of TB in Indonesia is $395 / 100.000$ cases population with mortality rate of 40/100.000 cases population and 10 TB-HIV sufferers per 100.000. Based on data from survey results with calculation model prediction prevalence tuberculosis 2013-2014, in 2015 
estimation of tuberculosis prevalence equal to 643 per 100.000 population and year 2016 equal to 628 per 100.000 population. In the National Medium-Term Development Plan (RPJMN) 2015-2019, the indicator used is microscopic-only prevalence alone so that the figure is lower than the prevalence of tuberculosis prevalence in 2013-2014 which already uses more sensitive methods of bacteriological confirmation including microscopic, molecular and culture examination. The 2015 target of tuberculosis prevalence in RPJMN is $280 / 100.000$ population with achievement of $263 / 100.000$ population and in 2016 at $271 / 100.000$ population $271 / 100.000$ population with achievement of 257/100.000 population [4].

According to a previous study of Pasaribu Marsinta (2012) in Polonia Polonia Medan, there were several variables that influenced the healing of tuberculosis patients by using multivariate analysis that is family support value $\mathrm{p}=0,001$; OR: 23.11, 95\% CI (3.151-169.601), income $\mathrm{p}=0.001$; OR 14.083, 95\% CI (1.914-103.622) and knowledge $\mathrm{p}$ value of 0.001 ; OR $13.35,95 \%$ CI (3.178-56.125) [5]. These results indicate that family support, income and knowledge affect TB recovery. Another study by Ai Xianqin, et al. (2010) in remote poor areas of Shaanxi Province, China showed that there was a significant effect between stopping treatment on tuberculosis recovery rates where $\mathrm{p}=0.001$; OR 8.41 (95\% CI 3.85-18.37) means TB patients who stopped treatment 8.41 times risk not recovered compared with TB patients who did not stop treatment or complete treatment as determined by health personnel. Success rate is also supported by the performance of the Supervisor of Drugs Swallowing [PMO] in which patients who are under-supervised poor 1.83 times are at risk of not recovering compared with patient of good the PMO [6].

Based on data from the Provincial Health Office of North Sumatra (2015), the number of suspect TB as many as 182.257 people while the number of smear positive TB as many as 18,370 people and the recovery rate of $82.83 \%$ (14,178 people). Medan City is the city with the highest positive AFB TB case in North Sumatera and the cure rate is still below the national target of 74.02. The total number of TB cases in Medan City was 6,362 people, the proportion with positive acid resistant bacteria examination was $44.46 \%$ (2.829 persons) 2,853 people treated and $74.02 \%(2.112$ persons) recovered proportion. Medan city is one of district or city in North Sumatera province with high TB incidence and cure rate which is still below national target that is $74.02 \%$. Therefore researchers interested in conducting research "Determinant analysis of recovery treatment for tuberculosis patients in Medan City".

\section{MATERIAL AND METHODS}

This research was conducted at Puskesmas in Medan City with TB recovery rate under national target more than $85 \%$. The type of research is observational analytics with cases control study design. Observational analytic research is one of the epidemiologi studies aimed at examining the relationship between effects (disease or health conditions) on risk factors. The case control study design study was used to assess how big the role of disease risk factors [7]. The implementation of research from August to October 2017.
Data sources are primary data and secondary data. Data obtained directly from the respondents using questionnaires while secondary data from Medan City Health Office. The study population was all TB patients in Medan City. The population of the case is all more than 15 years old tuberculosis patients who did not recover in Medan city from January 2015 until september 2017. The control population is all tuberculosis patients aged more than 15 years who recovered in the treatment period from January 2015 until September 2017. Sampling technique in this research is consecutive sampling and systematic random sampling. The consecutive sampling technique is a technique of determining the sample among the population in accordance with the desired by researchers [8].

The reason the researchers make consecutive sampling in this study because of the limitations of research samples for sample cases and time and funds owned by researchers. How to take samples of cases that meet certain criteria to obtain a number of samples available in this study is to sample cases of TB patients who did not recover at the end of treatment and did not suffer from disease complications. Systematic random sampling technique for control samples where TB patients are cured at the end of treatment. The way to sort patients who recover in 2016 until 2017 and then selected a particular order systematically from the list of all TB patients who recover.

From the calculation result, obtained the minimum sample size is 70. This study used case comparison and control 1: 1 then the case in this study amounted to 70 respondent and control amounted to 70 respondent. A total number of 140 samples. This research using tool questionnaires to obtained information about the characteristics of respondents then further know the variables, knowledge, nutrional status and medication compliance and weight scales and centimeters to calculate the nutritional status of respondents.

The Statistical Package for Social Science (SPSS) program was used for data analysis. Information on nutritional status, knowledge and compliance of respondent treatment were calculated and cross tabulated. The influence knowledge, nutritional status and medication compliance of tuberculosis recovery is checked using multiple logistic regression. Initially the data were analyzed using simple logistic analysis to select a significant variable with a $\mathrm{p}$ value of less than 0.25 then significant variables included in multiple logistic regression with the entere method. Then followed by model equation analysis on the significant variables in the multivariate model [9]

\section{RESULT}

Ouput research in medan city of the majority of respondent $15-49$ year old in the case group as many as 48 people $(68.6 \%)$ and the control group as many as 44 people $(62.9 \%)$. The majority of male respondents were male $(53.7 \%)$ and control group as many as 49 people (70\%), Marriage Status majority respondents married in the case group as many as 37 people $(52.9 \%)$ and the control group as many as 46 people $(65.7 \%)$. The majority of respondents tribe of Javan tribe in case group are 20 people $(28.6 \%)$ and control group counted 25 people 
(35.7\%). The majority of high school education in the case group as many as 26 people (37.1\%) and the control group as many as 33 people $(47.1 \%)$ (Table 1$)$.

Education of uncured for TB patients of the majority with low education and poor income. Based on the nutrition status of uncured for TB patients the majority with malnutrition and poor family support. Based on the medication compliance of uncured for TB patient the majority not adhrence and poor the performance PMO (Table 2). The results of simple logistic regression obtained the significant variable with $\mathrm{p}$ value less than 0.25 : education, income, nutrition status, family support, medication compliance, the role PMO and knowledge (Table $3)$. These variables then were included in the multiple logistic regression and the result as presented in (Table 4).

Based on the results of multiple logistic regression with method Forward LR showed the dominant variable is nutrition status, medication compliance and knowledge where p-value less than 0.05 and Odds Raio (OR) more than 1 . The results multicolinearity Hosmer Lemeshow test $p$ value more than 0.05 and fit model value Varian Inflation Factors (VIF) less than 10 and Receiver Operator Curve (ROC Curve) more than $50 \%$.

\section{TABLE I. CHARACTERISTICS OF RESPONDENTS IN MEDAN CITY}

\begin{tabular}{|c|c|c|c|}
\hline \multirow[b]{2}{*}{ No } & \multicolumn{3}{|c|}{ Recovery Treatment for Tuberculosis patients } \\
\hline & $\begin{array}{l}\text { Characteristics } \\
\text { Respondents }\end{array}$ & $\begin{array}{l}\text { Uncured } \\
\text { n }(\%)\end{array}$ & $\begin{array}{l}\text { Cured } \\
\text { n }(\%)\end{array}$ \\
\hline 1 & $\begin{array}{l}\text { Age (Year) } \\
15-49 \text { year } \\
>49 \text { year }\end{array}$ & $\begin{array}{l}48(68,6) \\
22(31,4)\end{array}$ & $\begin{array}{l}44(62,9) \\
26(37,1)\end{array}$ \\
\hline 2 & $\begin{array}{l}\text { Sex } \\
\text { Female } \\
\text { Male }\end{array}$ & $\begin{array}{l}17(24,3) \\
53(75,7)\end{array}$ & $\begin{array}{l}21(30,0) \\
49(70,0)\end{array}$ \\
\hline 3 & $\begin{array}{l}\text { Marriage Status } \\
\text { Married } \\
\text { unmerried }\end{array}$ & $\begin{array}{l}37(52,9) \\
33(47,1)\end{array}$ & $\begin{array}{l}46(65,7) \\
24(34,3)\end{array}$ \\
\hline 4 & $\begin{array}{l}\text { Ethnic } \\
\text { Jawa } \\
\text { Batak } \\
\text { Mandailing } \\
\text { Minang } \\
\text { Melayu } \\
\text { Other }\end{array}$ & $\begin{array}{c}20(28,6) \\
24(34,3) \\
11(15,7) \\
6(8,5) \\
3(4,3) \\
6(8,5)\end{array}$ & $\begin{array}{c}25(35,1) \\
12(17,1) \\
9(12,9) \\
16(22,9) \\
4(5,7) \\
4(5,7)\end{array}$ \\
\hline 5 & $\begin{array}{l}\text { Education } \\
\text { Illiterate } \\
\text { Primary School } \\
\text { Junior high school } \\
\text { Senior high school } \\
\text { College and above }\end{array}$ & $\begin{array}{c}2(2,8) \\
16(22,9) \\
23(32,9) \\
26(37,1) \\
3(4,3)\end{array}$ & $\begin{array}{c}5(7,1) \\
8(11,4) \\
18(25,7) \\
33(47,1) \\
6(8,7)\end{array}$ \\
\hline
\end{tabular}

TABLE 2 INDEPENDENT VARIABLE RECOVERY TREATMENT FOR TB

\begin{tabular}{|c|c|c|c|}
\hline \multirow{2}{*}{ No } & \multicolumn{3}{|c|}{ Recovery Treatment for Tuberculosis patients } \\
\hline & Variable & $\begin{array}{c}\text { Uncured } \\
\text { n }(\%)\end{array}$ & $\begin{array}{l}\text { Cured } \\
\text { n }(\%)\end{array}$ \\
\hline 1 & $\begin{array}{l}\text { Education } \\
\text { Low } \\
\text { High }\end{array}$ & $\begin{array}{l}41(58,6) \\
29(41,4)\end{array}$ & $\begin{array}{l}31(44,3) \\
39(55,7)\end{array}$ \\
\hline 2 & $\begin{array}{l}\text { Income } \\
\text { Poor } \\
\text { Good }\end{array}$ & $\begin{array}{r}63(90,0) \\
7(10,0)\end{array}$ & $\begin{array}{r}51(72,9) \\
9(27,1)\end{array}$ \\
\hline 3 & $\begin{array}{l}\text { Nutrition Status } \\
\text { Malnutrition }\end{array}$ & $49(70,0)$ & $10(14,3)$ \\
\hline
\end{tabular}

\begin{tabular}{|c|c|c|c|}
\hline \multirow[b]{2}{*}{ No } & \multicolumn{3}{|c|}{ Recovery Treatment for Tuberculosis patients } \\
\hline & Variable & $\begin{array}{c}\text { Uncured } \\
\text { n }(\%)\end{array}$ & $\begin{array}{l}\text { Cured } \\
\text { n }(\%)\end{array}$ \\
\hline & Good & $21(30,0)$ & $60(85,7)$ \\
\hline 4 & $\begin{array}{l}\text { Family Support } \\
\text { Poor } \\
\text { Good }\end{array}$ & $\begin{array}{c}64(91,4) \\
6(8,6)\end{array}$ & $\begin{array}{l}37(52,9) \\
33(47,1)\end{array}$ \\
\hline 5 & $\begin{array}{l}\text { Medication Compliance } \\
\text { NotAdhrence } \\
\text { Adhrence }\end{array}$ & $\begin{array}{c}64(91,4) \\
6(8,6)\end{array}$ & $\begin{array}{l}24(34,3) \\
46(65,7)\end{array}$ \\
\hline 6 & $\begin{array}{l}\text { The Role PMO } \\
\text { Poor } \\
\text { Good }\end{array}$ & $\begin{array}{c}65(92,9) \\
5(7,1)\end{array}$ & $\begin{array}{l}38(54,3) \\
32(45,7)\end{array}$ \\
\hline 7 & $\begin{array}{l}\text { Knowledge } \\
\text { Poor } \\
\text { Good }\end{array}$ & $\begin{array}{l}59(84,3) \\
11(15,7)\end{array}$ & $\begin{array}{l}30(42,9) \\
40(57.1)\end{array}$ \\
\hline
\end{tabular}

TABLE 3 FACTORS ASSOCIATED WITH RECOVERY TREATMENT FOR TB PATIENTS IN MEDAN CITY WITH SIMPLE LOGISTIC REGRESSION

\begin{tabular}{|c|c|c|c|c|}
\hline \multicolumn{4}{|c|}{ Recovery Treatment for Tuberculosis patients } & \multirow[b]{2}{*}{$\mathbf{p}$} \\
\hline Variable & $\begin{array}{l}\text { Uncured } \\
\text { n }(\%)\end{array}$ & $\begin{array}{l}\text { Cured } \\
\mathbf{n}(\%)\end{array}$ & $\begin{array}{c}\text { Crude OR } \\
(95 \% \text { CI })\end{array}$ & \\
\hline $\begin{array}{l}\text { Education } \\
\text { Low } \\
\text { High }\end{array}$ & $\begin{array}{l}41(58,6) \\
29(41,4)\end{array}$ & $\begin{array}{l}31(44,3) \\
39(55,7)\end{array}$ & $\begin{array}{c}1,78 \\
(0,91-3,47)\end{array}$ & 0,090 \\
\hline $\begin{array}{l}\text { Income } \\
\text { Poor } \\
\text { Good }\end{array}$ & $\begin{array}{r}63(90,0) \\
7(10,0)\end{array}$ & $\begin{array}{c}51(72,9) \\
9(27,1)\end{array}$ & $\begin{array}{c}3,35 \\
(1,30-8,60)\end{array}$ & 0,008 \\
\hline $\begin{array}{l}\text { Nutrition Status } \\
\text { Malnutrition } \\
\text { Good }\end{array}$ & $\begin{array}{l}49(70,0) \\
21(30,0)\end{array}$ & $\begin{array}{l}10(14,3) \\
60(85,7)\end{array}$ & $\begin{array}{c}11,50 \\
(5,01-26,41)\end{array}$ & 0,001 \\
\hline $\begin{array}{l}\text { Family Support } \\
\text { Poor } \\
\text { Good }\end{array}$ & $\begin{array}{c}64(91,4) \\
6(8,6)\end{array}$ & $\begin{array}{l}37(52,9) \\
33(47,1)\end{array}$ & $\begin{array}{c}9,51 \\
3,64-24,83)\end{array}$ & 0,001 \\
\hline $\begin{array}{l}\text { Medication } \\
\text { Compliance } \\
\text { Not Adhrence } \\
\text { Adhrence }\end{array}$ & $\begin{array}{c}64(91,4) \\
6(8,6) \\
\end{array}$ & $\begin{array}{l}24(34,3) \\
46(65,7) \\
\end{array}$ & $\begin{array}{c}20,44 \\
(7,73-54,01)\end{array}$ & 0,001 \\
\hline $\begin{array}{l}\text { The Role PMO } \\
\text { Poor } \\
\text { Good }\end{array}$ & $\begin{array}{c}65(92,9) \\
5(7,1)\end{array}$ & $\begin{array}{l}38(54,3) \\
32(45,7)\end{array}$ & $\begin{array}{c}10,94 \\
(3,93-30,48)\end{array}$ & 0,001 \\
\hline $\begin{array}{l}\text { Knowledge } \\
\text { Poor } \\
\text { Good }\end{array}$ & $\begin{array}{l}59(84,3) \\
11(15,7)\end{array}$ & $\begin{array}{l}30(42,9) \\
40(57,1) \\
\end{array}$ & $\begin{array}{c}7,15 \\
(3,21-32,71)\end{array}$ & 0,001 \\
\hline
\end{tabular}

TABLE 4 FACTORS ASSOCIATED WITH RECOVERY TREATMENT FOR TB IN MEDAN CITY WITH MULTIPLE LOGISTIC REGRESSION.

\begin{tabular}{|c|c|c|c|c|}
\hline \multicolumn{4}{|c|}{ Recovery Treatment for Tuberculosis patients } & \multirow[b]{2}{*}{$\mathbf{p}$} \\
\hline Variable & $\begin{array}{l}\text { Uncured } \\
\text { n }(\%)\end{array}$ & $\begin{array}{r}\text { Cured } \\
\text { n }(\%)\end{array}$ & $\begin{array}{c}\text { Adjusted OR } \\
(95 \% \text { CI })\end{array}$ & \\
\hline $\begin{array}{l}\text { Nutrition Status } \\
\text { Malnutrition } \\
\text { Good }\end{array}$ & $\begin{array}{l}49(70,0) \\
21(30,0)\end{array}$ & $\begin{array}{l}10(14,3) \\
60(85,7)\end{array}$ & $\begin{array}{c}6,98 \\
(2,46-19,80)\end{array}$ & 0,001 \\
\hline $\begin{array}{l}\text { Medication } \\
\text { Compliance } \\
\text { Not Adhrence } \\
\text { Adhrence }\end{array}$ & $\begin{array}{c}64(91,4) \\
6(8,6) \\
\end{array}$ & $\begin{array}{l}24(34,3) \\
46(65,7) \\
\end{array}$ & $\begin{array}{c}15,681 \\
(5,16-47,63)\end{array}$ & 0,001 \\
\hline $\begin{array}{l}\text { Knowledge } \\
\text { Poor } \\
\text { Good }\end{array}$ & $\begin{array}{l}59(84,3) \\
11(15,7) \\
\end{array}$ & $\begin{array}{l}30(42,9) \\
40(57,1) \\
\end{array}$ & $\begin{array}{c}7,001 \\
(2,48-19,73)\end{array}$ & 0,001 \\
\hline
\end{tabular}

Forward LR Multiple Logistic Regression was applied. There was no interactionand multicolinearity Hosmer Lemeshow test $(\mathrm{p}=0.668$ ). Classification table overall correctly classified percentage $=83,6$ Area under the ROC curve $(90.3 \%)$ were applied to check the model fitness. 
TABLE 5 CORRELATION BETWEEN DEPENDENT VARIABLE AND INDEPENDENT VARIABLE

\begin{tabular}{|c|r|r|r|}
\hline Step & \multicolumn{1}{|c|}{ Chi-square } & df & \multicolumn{2}{|c|}{ Sig. } \\
\hline 1 & .000 & 0 & \\
2 & $\mathbf{1 . 0 8 9}$ & 2 & $\mathbf{5 8 0}$ \\
3 & $\mathbf{3 . 2 1 0}$ & 5 & $\mathbf{. 6 6 8}$ \\
\hline
\end{tabular}

TABLE 6 PREDICTION VARIABLE DETERMINANT FACTOR OF RECOVERY TREATMENT FOR TUBERCULOSIS PATIENTS IN MEDAN CITY

\begin{tabular}{|c|c|c|c|c|}
\hline \multirow[t]{2}{*}{ Area } & \multirow[t]{2}{*}{$\begin{array}{l}\text { Std. } \\
\text { Error }^{a}\end{array}$} & \multirow[t]{2}{*}{$\begin{array}{l}\text { Asymptotic } \\
\text { Sig. }^{b}\end{array}$} & \multicolumn{2}{|c|}{$\begin{array}{c}\text { Asymptotic 95\% Confidence } \\
\text { Interval } \\
\end{array}$} \\
\hline & & & Lower & Upper \\
\hline .903 & .025 & .000 & .854 & .953 \\
\hline
\end{tabular}

\section{DISCUSSION}

Tuberculosis is still a global problem in the world because of the increasing incidence of TB and the low recovery of treatment under target more than $85 \%$ by the World Health Organization. Therefore the Directly Observed Treatment Shortcourse (DOTS) program has become the right choice for tuberculosis control in all public and private health facilities including lung disease specialist private practice. Effective prevention in efforts should be made is the promotion of health to tuberculosis patients and their families about the importance of treatment compliance and knowledge to cure tuberculosis so that the awareness of tuberculosis patients to change their behavior.

In this study nutritional status is a significant factor for the recovery of tuberculosis patients in Medan City with $\mathrm{p}$ value 0.001 and Odds Ratio 6.98 (CI 95\% 2.46-19.80) meaning tuberculosis patient with malnutrition status 6.98 times risk not recovered compared to with tuberculosis nutritional status. This nutrional status is very instrumental to help the recovery process of tuberculosis patients. Malnutrition status in addition to inhibit the process of cure of tuberculosis also facilitate tuberculosis diseases relapse again. Similar findings reported by Maimati Rena et al (2017) in Xinjiang, China, found that malnutrition effect on the recovery of tuberculosis patients [10]. Another study by Amaliah (2012) in Bekasi showed that malnutrition effected on the failure of tuberculosis conversion with p 0.009 and Odd ratio 3.465 (CI 95\% 1. 360-8.826) [11].

This study is also accordance with Ai Xianqin in Remote Poor Areas of Shaanxi Province, China showed there is an influence of nutritional status on the recovered of tuberculosis patients at the end of treatment with $\mathrm{p}$ value of 0.018 and Odd Ratio 2.150 (CI 95\% 1.138-4.061)[6]. Another study was not in accordance with the results of research Kholifah (2009) in Lung Diseses Treatment Hall Salatiga (Balai Pengobatan Penyakit Paru-Paru) or abbreviated BP4 Paru showed not significant relationship between nutritional status with recovery tuberculosis patients [12]. In Indonesia, the problem of malnutrition and over weight to impacted influence work productivity special in tuberculosis patients so that monitoring sustainable. Morbidity and mortality due to malnutrition status is highest in developing coutries. The success of tuberculosis treatment is influeced by the optimal immnune system.

According Soemirat JS (2017) malnutrition in general will affect the strength, endurance and immunological response to disease from poisoning. Tuberculosis resistance is caused by malnutrition and decreased immune status (Garcia et al, 2009). Tuberculosis germs can affect all people in the state of the immune system decline, malnutrition and low rest mention malnutrition status can complicate the recovering process of tuberculosis and facilitate recurrence TB. The Researcher assumption that nutritional status plays an important role in the recovery process of tuberculosis because with good nutritional status can help boost the immune system and prevent drug resistant TB therefore expected tuberculosis patients to consume nutritious and balanced diet [13].

According to researcher assumtion of nutritional status influence to recovery tuberculosis because most of patients tuberculosis that do not recovery with malnutrition. This is caused by various factors such as socio-economic (income) and medication compliance. Most people with tuberculosis in poor income (low-sosio economic) and not adherence tuberkulosis treatment. Poor income (low-sosio economic) causes the inability to meet the need of such balanced nutrition which tuberculosis sufferers needs balanced nutrition to help the recovery process of tuberculosis. In addition tuberculosis treatment adherence has an impact on good nutritional status in which someone who regularly take medicine will increased the appetite of tuberculosis.

Medication compliance is also a factor that affects the recovery of tuberculosis patients in Medan City with $\mathrm{p}$ value 0.001 and Odds Ratio 15.681 (CI 95\% 5.16-47.63) meaning tuberculosis patients not adhrence treatment 15.681 times risk not recovered compared to with tuberculosis patient adherence treatment. Treatment failure is generally due to over treatment, irregular treatment and inappropriate combination of drugs. Treatment compliance influences the recovery of tuberculosis patients [14].

According is Danusantoso (2000) said theoretically all people with tuberculosis can be cured with the condition of tuberculosis patients obedient treatment until it is declared cured by health workers unless the beginning has been contaminated with germs that have resistant tuberculosis drugs. It can be understood that if the tuberculosis patients is obedient treatment so that the end result healed otherwise if the tuberculosis patient does not obedient ended with the treatment failure plus the incidence of tuberculosis multi resisten. Treatment failure is generally caused by overly short tuberculosis treatment, irregular copulation and inappropriate combination of drugs. Ai Xianqin's the research in Shaanxi Province states that the main factor of treatment failure is cessation of tuberculosis treatment. Patients with well-behaved tuberculosis treatment can increase the rate of recovery. This study is accordance with Tirtana (2011) the result of study in central Java showed is an significant influence adherence tuberculosis treatment with treatment success in tuberculosis 
patiens with tuberculosis drug reistance where the $\mathrm{p}$ value was obtained 0.001 dan Ratio Prevalence 2.82 (CI 95\% 0.46-2.13) [15]. Another the study was similar with Niviasari (2015) in Semarang City showed there is significant influence adhrence tuberculosis with the recovery status of patients tuberculosis where $\mathrm{p}$ value 0.001 and Odds Ratio 7,7 (CI $95 \%$ 2.45-24.49).

According to of the Indonesia Ministry of Health (2006) in the study of Widiyanto (2016) stated the compliance of pulmonary tuberculosis treatment is important because if treatment is not finish regularly then there will be immnunity of tuberculosis germs against tuberculosis drug or Multi Drugs Resistance (MDR). In general people with tuberculosis take medicine for six months to ensure the recovery but some circumtances may be longer. Tuberculosis patients should take medication according to established the implementation guidelines until completion within the treatment period. The measurement of the regularity of patients taking tuberculosis medication based on tuberculosis treatment regimen that health workers have set for completion within six months while non-adherence is seen in the intensive phase if more than 3 days are not taking the drug and the follow up phase is more than one week.

Knowledge is one of the factors that influence the healing of tuberculosis in Medan City with $\mathrm{p}$ value 0.001 and Odds Ratio 7.001 (CI 95\% 2.48-19.73) meaning tuberculosis patient with poor knowledge 7.001 times risk not recovered compared to with of tuberculosis patients good knowledge. The same discovery by amaliah (2012) in Bekasi which showed knowledge influences the conversion of tuberculosis with $\mathrm{p}$ value 0.001 and Odds Ratio (OR) 4.00 (CI 95\% 1.701-9.407). Another study by Pasek (2013) in Puskesmas Buleleng I showed p value 0.040 and Odds Ratio (OR) 16.8 (CI 95\% 1.13-248.57) where meaning there is a significant influence between knowledge with treatment compliance [17]. The result of this study is supported by research Dhewi (2010) in BKPM Pati showed that there is influence of knowledge on the adherence of taking medicine in lung tuberculosis patients with $\mathrm{p}$ value 0.001 and Odds Ratio 3.857 (CI 95\% 1.9537.619).

According to Notoadmodjo (2010) knowledge shapes behavior. individuals performing disease prevention and treatment measures are driven by the impact of the disease on individuals or the communities. As well as the pulmonary tuberculosis patients treatment of compliance due to pulmonary Tuberculosis disease that affects death [8]. The risk of severe illness, the more likely the individual or the community feels threatened. Such threats encourage individuals to take preventive measures and cure diseases. Precautions and treatment will be done indivdu or community if the disease has a serious impact. Healthy behavior is an effort to maintain and improve health is done in the form of illness prevention, personal hygiene, exercise and nutritious food. Human action is also a series of human activities can be directly by others. Such as smoking, drinking alcohol, drugs and others.

According to the assumptions of researchers related to knowledge with the recovery tuberculosis is tuberculosis patients who are not getting information about efforts to prevent and control tuberculosis disease obtained from health workers or other media so that change the behaviour of tuberculosis patients to recovery the disease. Knowledge related to education where the result of this study indicate that most of the education of tuberculosis sufferers who do not recover with low education (Illiterate, primary scholl, and junior high school) are 41 people $(58 \%)$. This research is used as a basis for counselling about tuberculosis, prevention and control of pulmonary tuberculosis in improving the recovery of patients.

Our study reveated that the nutrition status, medication compliance and knowkledge about tuberculosis have been proven to significantly influence recovery treatment for tuberculosis patients in Medan City. It was recommended to enhacethe health promotion of tuberculosis recovery efforts during tuberculosis treatment and prevention of tuberculosis relapse. In addition, efforts are made to all health facilities in both public and private in Medan City to implement the Directly Observed Treatment Shortcourse (DOTS) program strategy.

\section{ACKNOWLEDGMENTS}

We are grateful to the head of the Medan City Health Service for their assistance in this regard. We are also grateful to the existing Puskesmas in Medan City of the participants who areinvolved in this research. There is no conflict of interest.

\section{REFERENCES}

[1] World Health Organization (WHO), Global Tuberculosis Control WHO Report Surveilance, Planning, Financing Geneva, 2016.

[2] Muture N Bernard et al, Factors Associated With Default For Treatment Among Tuberculosis Patients In Nairobi Province Kenya A Case Control Study. BMC Public Health, 2011.

[3] World Health Organization (WHO), Global Tuberculosis Control , Report Surveilance, Planning, Financing Geneva, 2017.

[4] Ministry Of Indonesia Ministry of Health of Indonesia. Report of Tuberculosis Diseases Cases in Indonesia. Jakarta, 2017. Kementerian Kesehatan Republik Indonesia. Laporan Kasus Penyakit Tuberkulosis di Indonesia, Jakarta, 2017

[5] Pasaribu Marsinta, Thesis : Family Relationships And Characteristics Of Pulmonary TB Patients With Recovery At Pulmonary TB Treatment In The Working Area of Puskesmas Polonia Medan. Medan, 2012. Pasaribu Marsinta, Tesis : Hubungan Dukungan Keluarga dan Karakteristik Tuberkulosis Paru Dengan Kesembuhan Pada Pengobatan Tuberkulosis Paru di Wilayah Kerja Puskesmas Polonia Medan, 2012.

[6] Ai Xianqin et.al, Factors Associated With Low Cure Rate of Tuberculosis in Remote Poor Areas of Shaanxi Province, China: a Case Control Study. BMC Public Health 2010, 10:112.

[7] Sastroasmoro Sudigdo and Ismail Sofyan, Fundamentals of Clinical Research Methodology. CV : Sagung Seto Ed.4, Jakarta, 2013. Sastroasmoro Sudigdo dan Ismail Sofyan, Dasar-Dasar Metodologi Penelitian Klinis Edisi 4, Jakarta, 2013.

[8] Notoatmodjo, S, Public Health Science and Art, Rineka Cipta, Jakarta, 2010. Notoatmodjo, S, Kesehatan Masyarakat Ilmu dan Seni, Rineka Cipta, Jakarta.

[9] Machfoedz Icham, Biostatistica, Yogyakarta: Fitramaya, 2011. Machfoedz Icham, Biostatistika, Yogyakarta : Fitramaya, 2011.

[10] Maimati Rena et al, High Prevalence and Low Cure Rate of Tuberculosis Among Patients With HIV In Xianjiang, China. BMC Infectious Diseases, 2017. 
[11] Amaliah R, Factors Associated With Conversion Failure of Pulmonary TB Patients Positive Phase Intensive Treatment in Bekasi Regency. Thesis Faculty of Public Health University of Indonesia, 2012. Amaliah R, Faktor-Faktor Yang Berhubungan Dengan Kegagalan Konversi Penderita Tuberkulosis Paru BTA Positif Pengobatan Fase Intensif di Kabupaten Bekasi. Thesis Fakultas Kesehatan Masyarakat Indonesia, 2012.

[12] Kholifah Nur, Analysis Factors Associated with Recovery of Pulmonary Tuberculosis Patients (Case Study in Lung Diseases Treatment Hall Salatiga Year 2008). Kholifah Nur, Analisis Faktor Yang Berhubungan dengan Kesembuhan Penderita TB Paru (Studi kasus di BP4 Salatiga Tahun 2008).

[13] Garcia, I.S, Blanco, A.R., Perez, J.L.V., Viejo, M.A.G., Hernandez, M.J.J., Lopez, O. and Asensio, A.N, Risk Factor for Multidrugs resistant Tuberculosis Unit in Madrid, Spain. Eur J ClinMicrobiolInInfect Dis, 28: 325-330, 2009.

[14] Crofton S.J and Fred M, Tuberculosis Clinis, Widya Medica, Jakarta, 2002. Crofton S.J dan Fred M, Tuberkulosis Klinis, Widya Medika, Jakarta, 2202.

[15] Tirtana Bertin Tanggap, Independent Factors in Affecting Suucessful Treatment Of Pulmonary Tuberculosis Patients With Tuberculosis Drug Resistance at Central Java District, 2011. Tirtana Bertin Tanggap, Faktor-Faktor Yang Memengaruhi Keberhasilan Pengobatan Pada Pasien Tuberkulosis Paru Dengan Resistensi Obat Tuberkulosis Di Wilayah Jawa Tengah, 2011.
[16] Niviasari Dhina Nurlita, Saraswati Lintang Dian and Martini, Factors related to the recovery status of tuberculosis people, Journal of public Health of the University Diponegoro, Volume 3, Number 3 April 2015 (ISSN : 2356-3346). Niviasari Dhina Nurlita, Saraswati Lintang Dian dan Martini, Faktor-Faktor Yang Berhubungan Dengan Status Kesembuhan Penderita Tuberkulosis Paru. Jurnal Kesehatan Masyarakat Universitas Diponegoro, Vol 3, Nomor 3, April 2015 (ISSN : 23563346).

[17] Pasek Made Suadnyani, Nunuk Suryani and K Pancrasia Murdani, Perception Relations and Level Of Knowledge Patients Tuberculosis With Treatment Compliance In Working Region Puskesmas Buleleng I, Journal Pasca, Vol 1, Number 1, 2013. Pasek Made Suadnyani, Nunuk Suryani dan K pancrasia Murdani, Hubungan Persepsi Dan Tingkat Pengetahuan Penderita Tuberkulosis Dengan Kepatuhan Pengobatan Di Wilayah Kerja Puskesmas Buleleng I , Jurnal Pasca Sarjana, Vol 1, Number 1, 2013.

[18] Dhewi Gendhis Indra, Armiyati Yunie and Supriyono Mamat, Relationship Between Knowledge, Patients Attitude and Support Family With Drugs Complaints On Patient Tuberculosis In BKPM Pati, 2010. Dhewi Gendhis Indra, Armiyati Yunie dan Supriyono Mamat, Hubungan Antara Pengetahuan, Sikap Pasien Dan Dukungan Keluarga Dengan Kepatuhan Minum Obat Pada Pasien TB Paru di BKPM Pati, 2010 . 